\title{
Medicinal Poisons
}

\author{
ManojBalachandran ${ }^{1}$, Vin Ravi Vaswani ${ }^{2}$ and Hashim $\mathrm{A}^{3}$ \\ ${ }^{1}$ Post Graduate, Department of Forensic Medicine \&Toxicology, Yenepoya Medical College, India \\ ${ }^{2}$ Prof and Head, Department of Forensic Medicine \&Toxicology, Yenepoya Medical College, India \\ ${ }^{3}$ Lecturer/Toxicologist, Department of Forensic Medicine \&Toxicology, Yenepoya Medical College, India
}

Submission: October 03, 2017; Published: October 16, 2017

*Corresponding author: Manoj Balachandran, Post Graduate, Department of Forensic Medicine \&Toxicology, Yenepoya Medical College, Mangalore, India, Email: bmanoj7@yahoo.co.in

\section{Abstract}

Almost all pharmaceutical substance is potentially poisonous if taken in sufficient dosages or for a long period. However, toxic and fatal consequences are most commonly accidental or suicidal, although homicide should always be borne in mind, even though it is rare [1].

\section{Introduction}

There is great variation in the drugs prescribed, used and most importantly available to the public in different countries. In many countries there are strict controls on the supply of drugs but many potentially lethal compounds are still available to the public without prescription in the shops. Where drugs are easily available they are by far the most common method of suicide and suicidal gestures. The subject has expanded so greatly that it properly belongs in the field of clinical toxicology rather than legal medicine [1].

\section{From Past to Present}

The history of poison stretches from before 4500 B.C. to the present day. Poisons have been used for many purposes across the span of human existence, most commonly as weapons, antivenoms and medicines. Poison has allowed much progress in branches, toxicology, and technology, among other sciences
[1]. Some medicinal plants like Corymbia citriodora were used against malaria due to their antiplasmodial activity [2]. Datura Stramonium is a widely used poisonous plant with great medicinal and economic value [3].

\section{Common Medicinal Poisons}

a) Analgesics,

b) Antidepressant and sedative drugs,

c) Barbiturates,

d) Seda-tive hypnotic non-barbiturate,

e) Analgesic- antipyretic,

f) Antimanic agents

g) Insulin [1] (Table 1).

Table 1: Tests for Detecting Medicinal Poisons.

\begin{tabular}{|c|c|c|c|}
\hline Serial No. & Name of drug & Test performed & Results \\
\hline 1 & 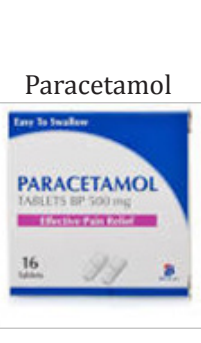 & $\begin{array}{l}\text { Qualitative test A trong, royal blue colour Applicable } \\
\text { to urine, stom- developing immediately ach contents } \\
\text { and scene indicates the presence of residues. } \\
\text { Method } \\
\text { 1. Add } 0.5 \mathrm{ml} \text { of hydro-chloric acid to } 0.5 \mathrm{ml} \text { of } \\
\text { sample, boil for } 10 \text { minutes and cool. } \\
\text { 2. Add } 1 \mathrm{ml} \text { of o-cresol solution to } 0.2 \mathrm{ml} \text { of the } \\
\text { hydrolysate. } \\
\text { 3. Add } 2 \mathrm{ml} \text { of ammonium hydroxide solution and } \\
\text { mix for } 5 \text { seconds. }\end{array}$ & $\begin{array}{c}\text { A strong royal blue colour } \\
\text { developed immediately indicates } \\
\text { the presence of Paracetamol }\end{array}$ \\
\hline
\end{tabular}




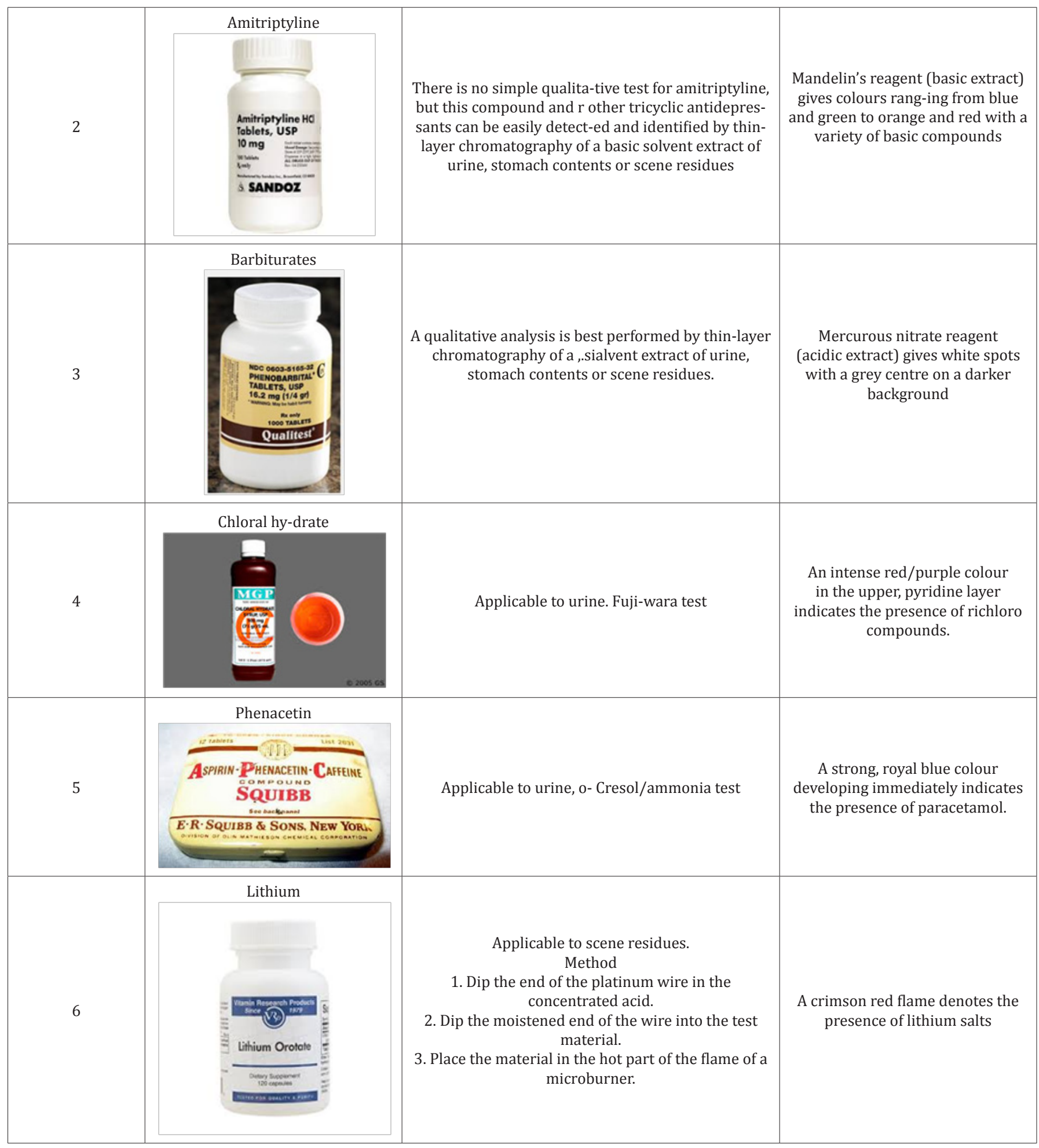

\section{Doctrine of Double Effect}

The doctrine of double effect says that if doing something morally good has a morally bad side-effect, it is ethically correct to do it provided the bad side-effect wasn't intended. This is true even if the bad effect is unavoidable. This principle has been seriously argued in ethics. According to the traditional Catholic conviction if there are exception less norms prohibiting inflicting some kinds of harms on people is correct, then double effect is justified and necessary [4]. The principle is used to justify the case where a doctor gives drugs to a patient to relieve distressing symptoms even though he knows doing this may shorten the patient's life. This is because the doctor is not aiming directly at killing the patient - the bad result of the patient's death is a side-effect of the good result of reducing the patient's pain. Many doctors use this doctrine to justify the use of high doses of drugs such as morphine for the purpose of relieving suffering 
in terminally-ill patients even though they know the drugs are likely to cause the patient to die sooner [1]. The value of doctrine of double effect is of special importance in euthanasia and abortion [5].

\section{Conclusion}

All pharmaceutical substances are to be taken in the correct dosage for the correct period of time. In case of over-dosage, it is important to identify the drug ingested so that resuscitative measures can be initiated rapidly. Doctrine of double effect where the doctor gives drug to a patient to relieve distressing symptoms even though he knows doing this may shorten the patient's life should be used with caution.

\section{Acknowledgement}

I would like to thank the teaching, non teaching staffs and PGs of Department of Forensic Medicine, Yenepoya Medical
College, Mangalore for their help and guidance in making this poster.

\section{References}

1. Shepherd R (2003) Simpson's Forensic Medicine Twelfth Edition. Arnold Publications 25:170-174.

2. Singh N, Kaushik NK, Mohanakrishnan D, Tiwari SK, Sahal D (2015) Antiplasmodial activity of medicinal plants from Chhotanagpur plateau, Jharkhand, India- J Ethnopharmacol 165:152-62.

3. Yang Y, Dang Y, Li Q, Lu J, Wang Y (2014) Complete chloroplast genome sequence of poisonous and medicinal plant Datura Stramonium organisations and impli-cations for genetic engineering. PLoS One 9(11): e110656.

4. Shaw AB (2002) Two challenges to the double effect doctrine: euthanasia and abor-tion. J Med Ethics 28: 102-104.

5. Boyle Joseph (1991) Who is entitled to double effect. The Journal of Medicine and Philosophy 16: 475-494.

\section{Your next submission with Juniper Publishers} will reach you the below assets

- Quality Editorial service

- Swift Peer Review

- Reprints availability

- E-prints Service

- Manuscript Podcast for convenient understanding

- Global attainment for your research

- Manuscript accessibility in different formats

( Pdf, E-pub, Full Text, Audio)

- Unceasing customer service

Track the below URL for one-step submission https://juniperpublishers.com/online-submission.php 